\title{
From Haugen's codification to Thomas's purism: assessing the role of description and prescription, prescriptivism and purism in linguistic standardisation
}

\section{Wendy Ayres-Bennett ${ }^{1}$ (D)}

Received: 13 June 2018 / Accepted: 9 April 2019 / Published online: 22 June 2019

(c) The Author(s) 2019

\begin{abstract}
Haugen's model (in Sociolinguistics, Penguin, Harmondsworth, pp 97-111, 1972 [1966]) of standardisation has been widely adopted in general histories of particular languages, not least because of its clarity and simplicity. In this article, I focus on its treatment of codification, with a view to suggesting refinements to this part of the model. In particular, I discuss the relationship between codification and prescription on the one hand, and between prescriptivism and purism on the other. Haugen makes no distinction between codification and prescription either in the original version of his model (Haugen 1972 [1966]), or in its revised version (Haugen in Blessings of Babel. Bilingualism and language planning problems and pleasures, Mouton de Gruyter, Berlin, 1987). Indeed, he seems to consider codification and prescription as broadly interchangeable, suggesting that the typical products of codification are a prescriptive orthography, grammar and dictionary. Whilst Milroy and Milroy (Authority in language: Investigating language prescription and standardisation, 2 edn, Routledge, London/New York, 1991) do differentiate codification and prescription, neither model mentions purism, although Deumert and Vandenbussche (Germanic standardisations: Past to present, John Benjamins, Amsterdam/Philadelphia, 2003) argue that it is essential to consider its role in the history of standardisation. I offer definitions of the different terms and argue that, when considering the role of prescriptivism and purism in linguistic standardisation, it is important to distinguish between the author's/work's intention, use of metalanguage, and effect. Finally, I adapt George Thomas's model for assessing purism to the assessment of prescriptivism, thereby avoiding viewing prescription and description as a simple dichotomy.
\end{abstract}

Keywords Codification · Prescription · Prescriptivism $\cdot$ Purism $\cdot$ Standardisation · Haugen · Thomas

Wendy Ayres-Bennett

wmb1001@cam.ac.uk

1 Faculty of Modern and Medieval Languages, University of Cambridge, MEITS, 17 Mill Lane,

Cambridge CB2 1RX, UK 


\section{Introduction}

In this article, I focus on the process of codification and consider how it relates, on the one hand, to the notions of description and prescription and, on the other hand, to prescriptivism and purism. ${ }^{1}$ I begin by examining Haugen's treatment of codification, noting the lack of any distinction between codification and prescription either in the original version of his model of standardisation (Haugen 1972 [1966]), or in its revised version (1987). ${ }^{2}$ In the following section, I briefly discuss another popular account of standardisation, Milroy and Milroy (1991), which builds on Haugen's account. While Milroy and Milroy do differentiate between codification and prescription, they, like Haugen, do not include purism in their account. For the remainder of the article, I consider how the codification stage of Haugen's model might be improved. I offer definitions of the different terms and argue that, when considering the role of prescriptivism and purism in linguistic standardisation, it is important to distinguish between the author's/work's intention, use of metalanguage, and effect. Finally, I adapt the model elaborated by George Thomas for evaluating the degree of intensity of purism in a given language situation and apply it to the assessment of prescriptivism, thereby avoiding viewing the distinction between prescription and description as a simple dichotomy.

\section{Haugen's model}

Haugen's model has been used to describe a range of European languages including French (Lodge 1993), Spanish (Penny 2000), the Germanic languages (Deumert and Vandenbussche 2003), Basque (Hualde and Zuazo 2007) and Catalan (Stillwell and Hetrovicz 2013). Whilst this list includes both national and minoritised languages, the model has apparently been above all exploited where there is a strong unitary standard language ideology.

Of the constellation of terms that are of interest to us-codification, prescription/ prescriptivism, purism—only codification features in Haugen's model in its first version (see Table 1).

The same is true of the revised 1987 version, although more detail is given here about how codification-glossed as 'standardisation procedures' and characterised as part of corpus planning-is conceived. Codification is broken down into the three sub-procedures of Graphization, Grammatication and Lexication (Table 2).

\footnotetext{
1 In broad terms, the term 'prescriptivism' is used, following the OED, to refer to 'the practice or advocacy of prescriptive grammar; the belief that the grammar of a language should lay down rules to which usage must conform', whilst 'prescription', itself underpinned by a prescriptive ideology, is used for the act of prescribing or the result of that prescription. In practice, some scholars use the terms more or less interchangeably. For further discussion of the terms, see the "Definitions" section below.

${ }^{2}$ I focus here on the formal and conscious mechanisms of standardisation, but it is important to remember that 'language standards' emerge before the emergence of 'standard languages'; see Ayres-Bennett (forthcoming).
} 
Graphization is derived from Ferguson (1968) and is glossed simply as 'reduction to writing' - which he seems to conceive principally as the development of a writing system for a previously unwritten language. For Auroux (1992: 11), the advent of writing constitutes the first 'révolution technico-linguistique' (technicolinguistic revolution). For later periods, the choice of the appropriate writing and orthographic system is a key feature of the standardisation of a written language. ${ }^{3}$ Haugen explains the second process, grammatication, in the following terms:

To some degree linguistics owes its existence to the practical services linguists could offer as codifiers of language. They learned to extract and formulate the rules of grammar, a process we may call grammatication. From Panini to the present grammars have been prescriptive, certainly the ones used in most schools. Whether they are also scientific depends on the skill of the linguist and the philosophy of the times (Haugen 1987: 60).

As the name implies, lexication involves the selection of the appropriate lexicon. Haugen notes that this may also involve the assignment of styles and spheres of usage for the words of the language, or what is sometimes called in lexicography the assignment of style labels.

The term grammatisation, as defined by Sylvain Auroux, ${ }^{4}$ has been widely adopted in the French school of the history of linguistics. In his approach, it embraces both grammar and vocabulary:

Par grammatisation, on doit entendre le processus qui conduit à décrire et à outiller une langue sur la base des deux technologies, qui sont encore aujourd'hui les piliers de notre savoir métalinguistique: la grammaire et le dictionnaire (Auroux 1992: 28).

(By 'grammatisation', we understand the process which leads to describing and 'tooling up' [equipping] a language on the basis of two technologies which are still today the pillars of our metalinguistic knowledge: grammars and dictionaries.)

The lack of distinction between codification and prescription in Haugen's account is confirmed in the conclusion to the description of the three sub-procedures; Haugen (1987: 60) writes: 'The typical product of codification has been a prescriptive orthography, grammar, and dictionary'.

Given the influence and impact of Haugen's model, it is not surprising that the same equation of codification with prescription is repeated elsewhere, for instance by Costa Carreras, writing on the emergence of a norm for Catalan. He makes no distinction between what is often termed 'the descriptive norm' and 'the prescriptive norm'; rather, the two are apparently coalesced:

\footnotetext{
${ }^{3}$ Haugen (1987: 60) observes that, 'Historically, most linguists came in after the fact'. Whilst the 'reduction to writing' of languages like English, French or German occurred pre-standardisation, linguists subsequently discussed the suitability of the system and proposed reforms and modifications.

${ }^{4}$ Note that Auroux (1992: 11) considers this to be the second technico-linguistic revolution.
} 
Table 1 Haugen's model of standardisation (1972 [1966]) bold added

\begin{tabular}{lll}
\hline & Form & Function \\
\hline Society & Selection & Acceptance \\
Language & Codification & Elaboration \\
\hline
\end{tabular}

Table 2 Haugen's revised model of standardisation (1987)—bold added

\begin{tabular}{|c|c|c|}
\hline & Form (policy planning) & Function (cultivation) \\
\hline Society (status planning) & $\begin{array}{l}\text { 1. Selection (decision procedures) } \\
\text { (a) Identification of problem } \\
\text { (b) Allocation of norms }\end{array}$ & $\begin{array}{l}\text { 3. Implementation (educational spread) } \\
\text { (a) Correction procedures } \\
\text { (b) Evaluation }\end{array}$ \\
\hline Language (corpus planning) & $\begin{array}{l}\text { 2. Codification (standardization } \\
\text { procedures) } \\
\text { (a) Graphization } \\
\text { (b) Grammatication } \\
\text { (c) Lexication }\end{array}$ & $\begin{array}{l}\text { 4. Elaboration (functional develop- } \\
\text { ment) } \\
\text { (a) Terminological modernization } \\
\text { (b) Stylistic development }\end{array}$ \\
\hline
\end{tabular}

cette opération [codification de la norme] équivaut à poser la norme sélectionnée comme norme prescriptive; c'est-à-dire, à attribuer en une liste de critères linguistiques ou sociolinguistiques, un statut prescriptif aux traits et aux formes linguistiques sélectionnés (Costa Carreras 2007: 288).

(codification of the norm is equivalent to establishing the selected norm as the prescriptive norm; in other words attributing, in a list of linguistic or sociolinguistic features, a prescriptive status to the linguistic features or forms selected).

\section{Milroy and Milroy's model}

James and Lesley Milroy in Authority in language: Investigating language prescription and standardisation $\left({ }^{1} 1985,{ }^{2} 1991\right)$ build on and develop Haugen's model. Their model has been used particularly in accounts of the standardisation of English (e.g. Nevalainen and Tieken-Boon van Ostade 2006; Tieken-Boon van Ostade 2011). In their work, the Milroys adopt a stricter interpretation of the term 'standardisation', arguing that its 'chief characteristic [...] is intolerance of optional variability in language' (1991: 26). As is clear in Table 3, they include rather more hypothetical stages in what they term the implementation of a standard language (Milroy and Milroy 1991: 27). ${ }^{5}$ Here, then, codification and prescription are differentiated.

\footnotetext{
5 This is sometimes presented as having seven, rather than eight hypothetical stages, with acquisition of prestige not being separated out (see for instance, Nevalainen and Tieken-Boon van Ostade 2006).
} 
Whilst the Milroys stress that these hypothetical stages do not necessarily follow one another in temporal succession, they equally seem to imply that codification precedes prescription:

the writing system serves as one of the sources of prescriptive norms, and prescription becomes more intense after the language undergoes codification [...] because speakers then have access to dictionaries and grammar-books, which they regard as authorities (Milroy and Milroy 1991: 27).

In practice, the Milroys focus on prescription in their volume and have little to say about codification. Similarly, the purist tradition is only alluded to briefly in relation to their discussion of George Orwell (1991: 45-46). In short, as with Haugen, there is a lack of clarity about the relationship between codification, prescription and purism.

\section{Definitions}

\section{Codification versus prescription}

Whilst, as we have seen, many linguists-including Haugen-have apparently used codification and prescription as quasi-synonyms, here I argue that they should be differentiated. In order to do this, I need to introduce another problematic opposition, that between description and prescription.

In our terms, codification is a neutral term, which refers to the production of grammars, dictionaries and other types of metalinguistic works, and is thus equivalent to Auroux's grammatisation. Codification may result in the production of either descriptive or prescriptive works. Descriptive texts are based on the descriptive norm; starting from the 'facts' or with usage, they describe what is 'normal', 'regular' or 'frequent' in language usage, without making a value judgment about it. ${ }^{6}$ The prescriptive 'norm' on the other hand is more subjective: here one thinks of an ideal model; the norm prescribes what should be said, or more usually written, based on value judgments (Figure 1). ${ }^{7}$ The prescriptive norm is typically based on the descriptive norm, that is, it often begins with the observation of usage, but then a notion of what is right and wrong, correct and incorrect, is added. Joseph (1987: 18) thus concludes that 'the prescriptive-descriptive dichotomy-or better, continuum-reduces essentially to the matter of conscious value judgment'. Other such as Trask (1999: 246) define prescriptivism as 'the imposition of arbitrary norms upon a language, often in defiance of normal usage' (emphasis added), thereby challenging the connection between the descriptive and prescriptive norm.

\footnotetext{
${ }^{6}$ In practice, the claim by linguists to be describing usage may not refer to the statistically most common usage, but rather to a socially normed language, or the usage of a particular group (the usage of 'ordinary people', of the educated, of linguistic authorities, etc.). In other words, where so-called descriptive grammars do not record the most frequent usage, there is inevitably selection and the possibility of an implied value judgment.

${ }^{7}$ Here I start by representing the opposition between description and prescription as a simple dichotomy, but I will argue that it is better conceived of as a continuum or cline.
} 
Table 3 The Milroy's model of standardisation (1991)—bold added

\section{Selection \\ 2. Acceptance \\ 3. Diffusion}

Once the selected variety is well established and has defeated its competitors:

4. Maintenance

5. Elaboration of function $\rightarrow$ more value for purely utilitarian ends

6. Acquisition of prestige $\rightarrow$ associated with the most successful people

7. Codification

8. Prescription

Moreover, prescriptivism has traditionally received a bad press; as Cameron (1995: 5) observes, it 'represents the threatening Other, the forbidden; it is a spectre that haunts linguistics'. Larry Trask in his Key concepts in language and linguistics (1999) is more acerbic in his condemnation of prescriptivism in his entry on descriptivism:

The policy of describing languages as they are found to exist. ${ }^{8}$ A prominent feature of traditional grammar is the frequent presence of prescriptivism: identifying and recommending forms and usages favoured by the analyst and condemning others not favoured by the analyst. Excepting only in certain educational contexts, modern linguists utterly reject prescriptivism, and their investigations are based instead upon descriptivism. [...] Descriptivism is a central tenet of what we regard as a scientific approach to the study of language: the very first requirement in any scholarly investigation is to get the facts right. Prescriptivism, in great contrast, is not a scientific approach. The strong opinions of prescriptivists may be variously regarded as recommendations about good style, as an aspect of social mores, as a consequence of our educational system, or perhaps even as a matter of morality, but they are not statements about actual behaviour, and hence they are not scientific.

Trask, then, goes so far as to argue that prescriptivism should not be part of linguistics. As Milroy and Milroy note (1991: 5), linguists have often studied language as if prescriptive phenomena play no part in language. Yet, as they go on to argue (1991: 9 ), if we are going to have a rounded picture of the nature of language, we cannot overlook its social functions and characteristics, which include understanding standardisation, questions of prestige, attitudes to language, or what Cameron calls 'verbal hygiene' which she considers a natural part of human behaviour.'

\footnotetext{
${ }^{8} \mathrm{Gal}$ (2006: 14) has pointed out that it is the standard language ideology, as invented in Europe, which assumes that languages are nameable, countable, bounded and differing from each other.

9 A number of scholars, most recently Armstrong and MacKenzie (2013), have pointed out there has been 'covert ideological influence' (Milroy 2001: 531) on a number of aspects of linguistic thinking, and that much linguistic theory has assumed and modelled the properties of standardised varieties and
} 


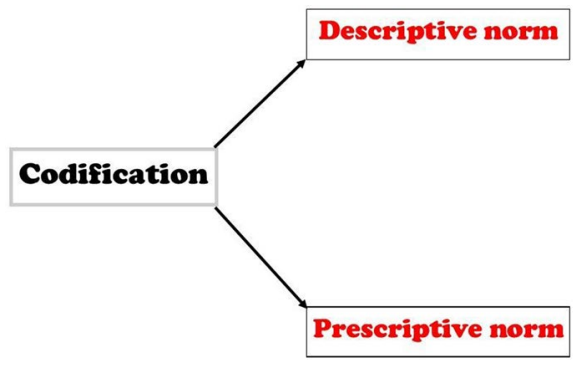

What is 'normal', 'regular' or 'frequent' in language usage
Addition of value judgment from 'usage' to 'good usage'

Fig. 1 Codification, description and prescription

In other accounts, some types of prescriptivism appear to be more acceptable to linguists than others. Curzan (2014: 24) identifies four overlapping strands of institutionalised prescriptivism: 'standardizing prescriptivism' (policing the boundaries of the standard); 'stylistic prescriptivism' (differentiating among points of style within standard usage); 'restorative prescriptivism' (turning to older forms to purify usage); and 'politically responsive prescriptivism' (politically correct language). Curzan observes that the LSA guidelines for non-sexist usage ${ }^{10}$ represent this last type of prescriptivism, as in the following extract:

1. Whenever possible, use plurals (people, they) and other appropriate alternatives, rather than only masculine pronouns and "pseudo-generics" such as man, unless referring specifically to males. [...]

2. Avoid generic statements which inaccurately refer only to one sex (e.g. "Speakers use language for many purposes-to argue with their wives..." or "Americans use lots of obscenities but not around women").

3. Whenever possible, use terms that avoid sexual stereotyping. Such terms as server, professor, and nurse can be effectively used as gender neutral; marked terms like

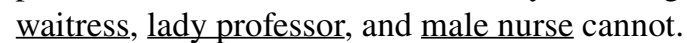

4. Use parallel forms of reference for women and men, e.g. do not cite a male scholar by surname only and a female scholar by first name or initial plus surname.

5. In constructing example sentences, avoid gender-stereotyped characterizations. [...]

Footnote 9 (continued)

have been subject to the influence of standard language ideology in their idea of what constitutes a language. Take, for example, the notion of grammaticality judgments in generative approaches. Armstrong and MacKenzie (2013: 106) go so far as to argue that the notion of grammaticality is ultimately a projection or an epiphenomenon of standardisation. Even within sociolinguistics, it has been usual to use the 'standard', 'prestige', or 'careful style' variant as the unmarked term, for instance in labelling well-known variables in English-so we talk about copula deletion rather than copula insertion.

10 https://www.linguisticsociety.org/resource/lsa-guidelines-nonsexist-usage (consulted May 2018). 


\section{Prescriptivism and its types}

Many linguists have observed that the opposition between descriptivism and prescriptivism is not clear-cut, a point to which I will return below. In order to understand prescriptivism better, it is also necessary to distinguish three different things when we are evaluating metalinguistic texts, namely whether the author/ work is:

1. Prescriptive in intention/purpose

Did the author set out to be prescriptive? Are the aims as explicitly stated in the preface or introduction to the metalinguistic text the same as the intended aims?

2. Prescriptive in expression

In analysing the use of metalanguage, we need to consider:

(a) If the work uses prescriptive language, whether this reflects:

- a prescriptive attitude

- a description of the dominant usage; or guidance about changing usage (e.g. which word/expression/construction is taking over as the dominant usage); or an indication of the different social or stylistic values associated with the usage, etc.

(b) If descriptive metalanguage is used, whether this reflects:

- a descriptive attitude

- (covert) prescriptive behaviour

3. Prescriptive in effect

What is the impact of the text? If it is prescriptive in effect, we need to examine whether the prescriptive influence was:

- a direct result of the original text

- a result of later versions of that text. Here we would include not only subsequent editions, but notably later compilations, or the integration of the work's content into different types of metalinguistic works (such as school grammars or usage guides)

- a result of later perceptions of that text. It is notable how often studies of particular so-called prescriptive texts begin by noting how little the text is actually read

- a result of the way people use the text

In other words, to what extent is the reputation of the text as prescriptive based on an analysis of the text itself or is it a result of later reworkings of that text? Or indeed on a misconception of the text? As Joseph (1987: 18) remarks, "unfortunately, even if one takes great pains to write a descriptive grammar, readers may impose a prescriptive interpretation on it'. In the discussion below I will show that, if you make these distinctions, certain 
so-called icons of prescriptivism are more complex than they would first appear.

\section{Purism}

As we have already seen, neither Haugen nor the Milroys include purism in their models. In the conclusion to their volume on Germanic standardisations, Deumert and Vandenbussche point out the importance of purism in standardisation and argue that its role needs to be explored further:

What role did (and does) linguistic purism play in the context of standardization and the formation and reproduction of national communities? The theme of purism occurs in an impressive number of the articles, not only as a historical phenomenon, but also in the specific guise of the present day opposition against the growing presence of the English language (Deumert and Vandenbussche 2003: 463).

Just as codification and prescription are sometimes used interchangeably, the distinction between prescriptivism and purism is also sometimes far from clear, as in Anne-Marie Brousseau's discussion of prescriptivism:

Par définition, le prescriptivisme linguistique prescrit et proscrit : il impose une vision normative d'une langue donnée en stipulant quelles en sont les propriétés acceptées (et donc acceptables) et quelles en sont les propriétés prohibées. [...] Si le prescriptivisme reconnaît l'existence de la variation linguistique, il ne reconnaît pas la légitimité de cette variation. Le prescriptivisme constitue somme toute une forme de purisme délégué, qui impose à autrui les objectifs de préservation de la pureté de la langue qu'il s'impose à lui-même (Brousseau 2011: 4).

(By definition, linguistic prescriptivism prescribes and proscribes: it imposes a normative vision on a given language by stipulating which properties are accepted (and therefore acceptable) and which properties are prohibited. [...] If prescriptivism recognizes the existence of linguistic variation, it does not recognise the legitimacy of this variation. In short prescriptivism constitutes a sort of delegated purism, which imposes on others the objectives of preserving the purity of the language which it imposes on itself.)

The same is true of Anne Curzan's account of prescriptivism in the history of English which, as we have seen, lists 'restorative prescriptivism' (turning to older forms to purify usage) as one of its four types of prescription.

Broadly speaking, definitions of purism may be either narrow or broad. In the narrow definition, purism is said to refer only to negative attitudes towards foreign elements. This, for example, is what we find in Brincat: 
Purism $[\ldots]$ consists of a conscious attitude by the language user or by the language legislator to avoid language contact (Brincat 2003: 155).

According to the broader definition, purism aims to protect the (standard) language from all kinds of 'contaminations', whether foreign borrowings or forms resulting from variation and change which are considered 'deviant' or 'impure'. This broader definition is found in George Thomas's study of linguistic purism:

Purism is the manifestation of a desire on the part of a speech community (or some section of it) to preserve a language from, or rid it of, putative foreign elements or other elements held to be undesirable (including those originating in dialects, sociolects and styles of the same language). It may be directed at all linguistic levels but primarily the lexicon. Above all, purism is an aspect of the codification, cultivation and planning of standard languages (Thomas 1991: 12).

In his conclusion, Thomas (1991: 195) hypothesises that purism, as he defines it, is a universal characteristic of standardised languages, ${ }^{11}$ since in his view no standard language can be open to all sources of enrichment indiscriminately. He elaborates various subtypes, including archaising, ethnographic, elitist, reformist and xenophobic purism (which corresponds essentially to the narrower definition). ${ }^{12}$

There have been a various attempts to differentiate prescriptivism and purism. Paveau and Rosier (2008), for instance, consider that purism adds in a polemical and often an emotional dimension to the discourse:

Le discours puriste se caractérise par une forte axiologie (ce qui se dit, ce qui ne se dit pas) [...] C'est un discours normatif qui use d'arguments esthétiques (beau/laid), politiques (langue de la liberté), linguistiques (clarté de la langue), métaphoriques (langue en bonne santé).

Le discours puriste se démarque cependant du discours normatif conventionnel, celui des grammaires, par son caractère volontiers polémique, sa nostalgie et sa rhétorique de la déploration ou du combat, sa visée assumée de prescription ou de censure (Paveau and Rosier 2008: 57).

(Purist discourse is characterised by a strong axiology (what is said, what isn't said) [...] It's a normative discourse which employs aesthetic (beautiful/ugly), political (language of freedom), linguistic (clarity of the language) and metaphorical (language in good health) arguments.

\footnotetext{
11 Purism is not, of course, limited to standardised languages. Brincat et al. (2003: viii) examine purism in minor, regional and endangered languages, and maintain that it can occur in societies where literacy is rare.

12 The first four subtypes relate to internal purism, whereas xenophobic purism relates to external factors. Note that the label 'xenophobic' is not intended to have any negative connotations (e.g. of racism) here.
} 
Purist discourse differs, however, from conventional normative discourse, that of grammars, through its deliberately polemical character, its nostalgia and its rhetoric of regret or combat, its assumed attitude of prescription or censure.)

Walsh (2016: 9) similarly points out that purism has elements in common with standardisation and prescriptivism, such as the notion that some elements of the language are desirable whilst others are not, but she suggests that purism goes further in introducing the following ideas:

- This language is currently pure and, therefore, to change it equals contamination, corruption or decline of some sort

- The language must be protected from this contamination and preserved in its current state (or, alternatively, if the language has already begun to be corrupted, the corrupted part must be removed)

Prescriptivism shares with purism the idea that there is only one 'correct' form of the language, but it is not inherently conservative, and Walsh maintains that prescriptive norms can therefore change. James Milroy (in Langer and Davies 2005: 325) makes a similar distinction between standardisation and purism. In his view, in the case of standardisation, the only purpose of adopting one form and rejecting another is to bring about uniformity, whereas for purism there is the additional consideration of whether the form is considered pure or impure (Figure 2).

As in the case of prescriptivism, we can further consider whether the author or text is: (1) purist in intention/purpose; (2) purist in expression; (3) purist in effect, giving us the schema shown in Figure $3 .{ }^{13}$ Such a schema could be used to begin to refine Haugen's category of codification (Table 4). ${ }^{14}$

\section{Intensity measures}

One of the virtues of Thomas's approach to purism is that he introduces a measure of intensity for purism which considers the extent to which non-puristic factors are taken into consideration (Thomas 1991: 170-171). He therefore differentiates:

- Mild purism which gives equal weight to functional and other non-puristic considerations

- Moderate purism which makes some concessions to these factors

- Extreme purism which ignores them.

\footnotetext{
${ }^{13}$ Just as a descriptive statement such as ' $\mathrm{X}$ is more frequent than $\mathrm{Y}$ ' can be turned into a prescriptive statement ' $\mathrm{X}$ is better than $\mathrm{Y}$ ', so it can be turned into a purist one: ' $\mathrm{X}$ is purer than $\mathrm{Y}$ (and therefore should not change)'.

${ }^{14}$ The other stages also require refinement, as proposed by other contributions to this special issue. One of the expert readers commented that prescription may form a bridge between codification and implementation, since it leads to the actual use of some linguistic forms (instead of others) and (social) acceptance. This might be particularly the case when we take into account the potential effects of prescription on language usage.
} 
For Thomas (1991: 35-38), non-puristic considerations refer to rational concerns, which are motivated by instrumental and ethical attitudes, whereas puristic considerations refer to non-rational concerns, motivated by affective and traditionalist attitudes. An example of an ethical attitude is the 'intelligibility argument' (1991: 49), according to which language elements unknown to the broad masses should be avoided on the grounds that they hamper intelligibility. Affective attitudes, on the other hand, are controlled by emotional and aesthetic factors. According to Thomas (1991: 39), 'purity' is an aesthetic notion closely associated with values such as 'wholeness', 'oneness', 'homogeneity', 'pristineness', 'correctness' and is used as an appraisive to provide positive characterisations of a referent. In taking account of these factors, care is needed, since non-puristic considerations may be invoked to justify or mask an essentially purist judgment.

Thomas (1991: 191-192) provides a checklist of the core features of purism in the form of a questionnaire, by means of which he claims a profile of purism can be completed for any given language. These criteria include (a) the weighting of non-puristic factors, i.e. weighting of rational concerns motivated by instrumental and ethical attitudes against purist concerns motivated by affective and traditionalist attitudes; (b) the configuration of the puristic orientation, i.e. whether the orientation is 'internal' or 'external'; (c) the degree of completion of the purification cycle, i.e. whether purism remains at the censorship stage, includes the offering of replacements or achieves censorship, etc. Alongside this, he produces a numerical index to help assess the impact of purism or an index of puristic intensity (Table 5). In his system, mild purism is assigned 1-2 on the scale, moderate purism 3-4 on the scale, and extreme purism 5 on the scale.

This system is applied and critiqued by Walsh (2016) in her study of purism in France and Quebec. We might, in the same way, use these criteria to measure whether particular authors or metalinguistic texts are more or less purist, thereby avoiding the pitfall of making a simple dichotomy between purist/non-purist. The assigning of a numerical value is far from simple, as Thomas himself concedes (1991: 174), 'the purely statistical approach is fraught with difficulties and, used in isolation, might provide a misleading, ambiguous or even meaningless assessment of the impact of purism'. Nevertheless, it mitigates against the twin difficulties of subjectivity in assessment and simplification into a plain dichotomy of purist/ non-purist.

Turning now to consideration of prescriptivism, in evaluating how prescriptive a particular text is, it might be helpful to have the same kind of scale of intensity, or at least to consider the relative weight of descriptive and prescriptive elements. Once again, this would allow us to see prescription and description as being part of a continuum or cline rather than discrete categories, and to characterise authors in a more nuanced way as being more or less prescriptive. I set out in Table 6 some possible metrics for assessing how prescriptive a particular writer/metalinguistic text is, which build in consideration of possible differences in intention/metalanguage/ effect, as outlined above.

The intensity criterion proposed are: 


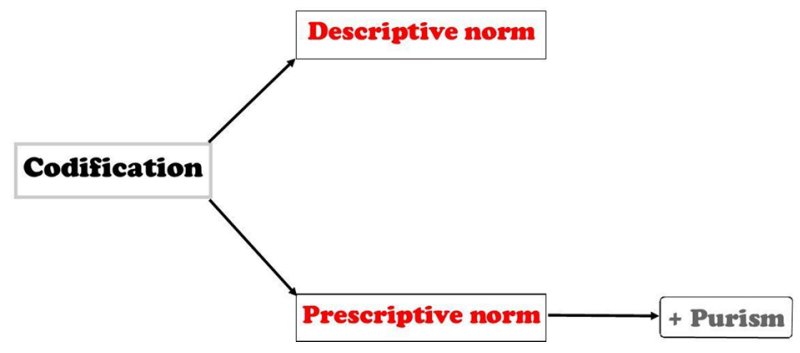

Fig. 2 Codification, prescription and purism

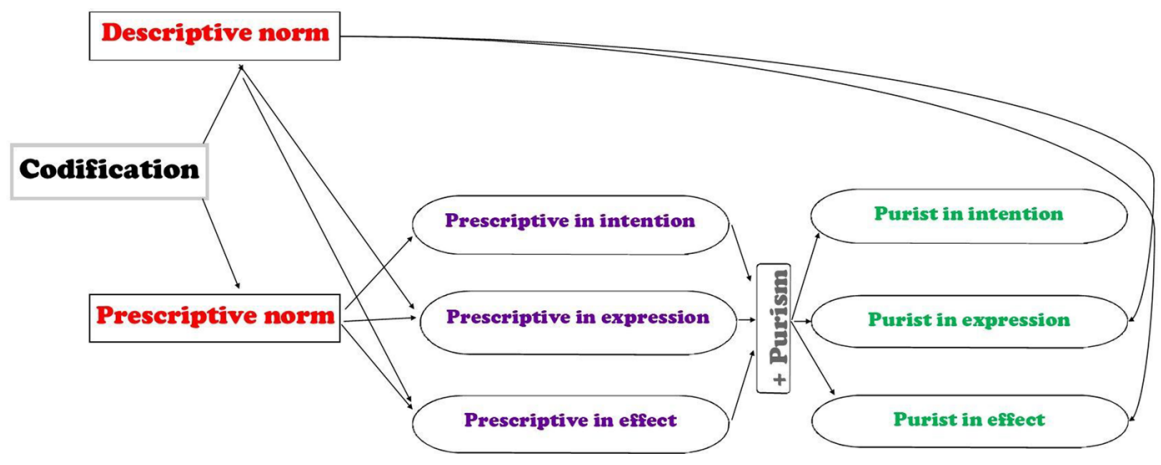

Fig. 3 Schematic view of the relationship between codification, prescription and purism

Table 4 Refining Haugen's model of codification

\begin{tabular}{lll}
\hline Society & Form & Function \\
\hline Language & Selection & Acceptance \\
\hline Prescriptive in effect & Elaboration & \\
\hline
\end{tabular}

(a) Weighting of non-prescriptive (descriptive) factors in expressions of intention:

- Mild prescriptivism gives more (1) or equal (2) weight to usage and other non-prescriptive considerations

- Moderate prescriptivism makes considerable (3) or some (4) concessions to these factors

- Extreme prescriptivism (5) ignores them 


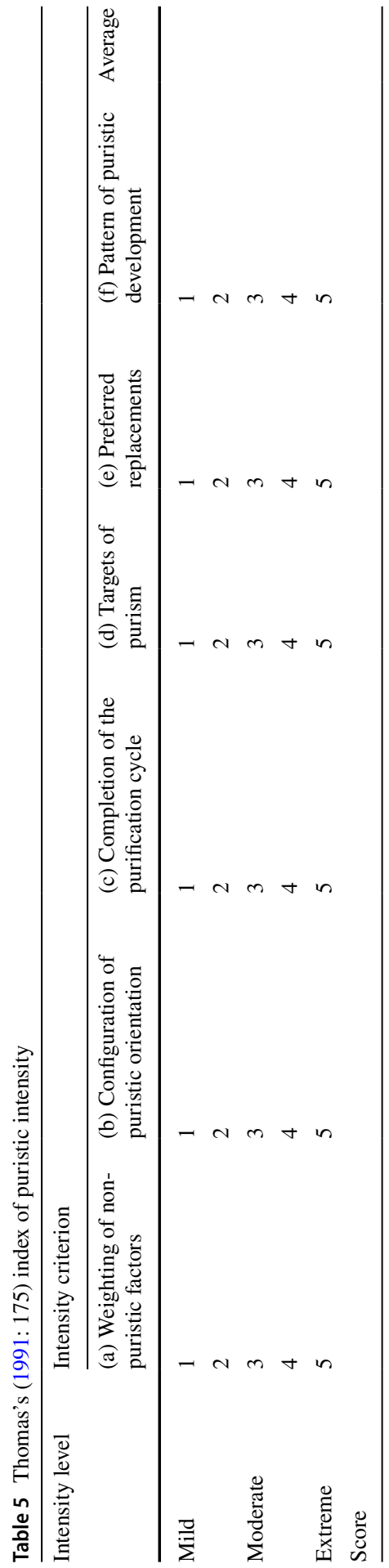




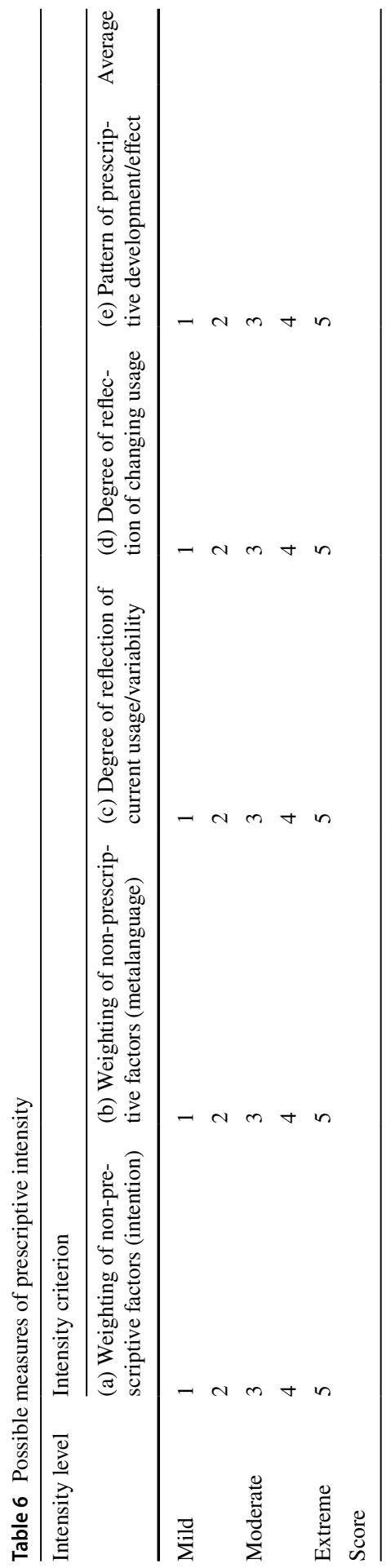


(b) Weighting of non-prescriptive (descriptive) elements in choice of metalanguage:

- Mild prescriptivism gives more (1) or equal (2) weight to descriptive/non-prescriptive metalanguage

- Moderate prescriptivism includes considerable (3) or some (4) use of descriptive/non-prescriptive meta-language

- Extreme prescriptivism makes no use (5) of descriptive/non-prescriptive metalanguage

(c) Degree of reflection of current usage/variability:

- Mild prescriptivism give more (1) or equal (2) weight to reflecting current usage and its variability

- Moderate prescriptivism gives considerable (3) or some (4) weight to these considerations

- Extreme prescriptivism pays no attention (5) to these considerations

(d) Degree of reflection of changing usage ${ }^{15}$ :

- Mild prescriptivism give more (1) or equal (2) weight to reflecting changing usage and recording the rise and dominance of new variants

- Moderate prescriptivism give considerable (3) or some (4) weight to reflecting changing usage and recording the rise and dominance of new variants

- Extreme prescriptivism takes no account of changing usage

(e) Pattern of prescriptive development/effect:

- Mild prescriptivism is when the author or text has no (1) or little (2) effect on subsequent usage

- Moderate prescriptivism is when the author or text has some (3) or considerable (4) effect on subsequent usage, either directly or indirectly

- Extreme prescriptivism is when the author or text changes usage (5), either directly or indirectly through subsequent reworkings or interpretations of the text

This list is not intended to be exhaustive, but rather to give an idea as to how the evaluation of prescription might become less impressionistic and more objective. Note that whereas Thomas allows only for giving at least equal weight to purist/ non-purist considerations under mild purism, I have also allowed for more weight to be given to non-prescriptive/descriptive considerations under my definition of mild prescription. This lowers the threshold for a text or author to be considered prescriptive compared with Thomas's scale for purism.

As in the case of Thomas's assessment of purism, assigning a numerical value for each criterion is far from simple, and the outcomes of the analysis should be seen only as providing guidance as to the degree of prescriptivism. The interpretation of metalanguage is particularly fraught with difficulties since, as Joseph (1987:

\footnotetext{
15 Our categories (c) and (d) are closely related, since variation is a prerequisite for change. I separate them here to signal that prescription may not only relate to diachronic variation, but also to diaphasic, diastratic and diatopic variation.
} 
18) asserted, a statement of the type 'The best speakers say x (not y)' differs only in syntax from the explicitly prescriptive statement 'Say x, not y'. Likewise, a comment stating that a word has 'meaning a' might tacitly imply that 'meaning b' is not acceptable. Any analysis of a text's metalanguage must therefore be mindful of these issues.

\section{Evaluating a so-called 'prescriptive icon'}

In order to illustrate this methodology, I re-examine a key figure in the history of the standardisation of French who has typically been considered as highly prescriptive (and sometimes also purist), and assess the extent to which this reputation is justified using the metrics proposed above. ${ }^{16}$ My example is Claude Favre de Vaugelas (1585-1650), author of Remarques sur la langue françoise utiles à ceux qui veulent bien parler et bien escrire (1647). Traditional accounts of Vaugelas typify him as a prescriptivist and purist. For instance, Coski (2011: 77) writes that Vaugelas sits firmly in the 'camp of prescriptive purism', whilst Cerquiglini $(2008: 7,10)$ characterises him in the following terms:

Vaugelas prescrit, certes avec prudence, réflexion et savoir, mais il prescrit. [...] une attitude s'impose au remarqueur, celle de la prescription. On attend de lui qu'il distingue, qu'il précise, qu'il réprouve; le purisme n'est jamais loin.

(Vaugelas prescribes, certainly with prudence, reflection and knowledge, but he prescribes [...] a certain attitude is required for a writer of observations, namely prescription. He is expected to distinguish, clarify and criticise. Purism is never far away.)

Vaugelas thus offers a good case study for illustrating our approach albeit, as yet, in a somewhat preliminary fashion.

\section{Weighting of non-prescriptive (descriptive) factors in expressions of intention}

Vaugelas acknowledges the variability of usage as illustrated in the following quotations ${ }^{17}$ :

Sur les armes, et sous les armes

[...] il faut user tantost de l'un \& tantost de l'autre, afin qu'il ne semble pas que l'on condamne celuy dont on ne se sert jamais, en quoy l'on auroit tort, \& pour conserver d'ailleurs tout ce qui contribuë à la richesse de nostre langue; comme est de pouvoir dire une mesme chose de deux façons, plustost que d'une seule (Vaugelas 1647: 396-397).

\footnotetext{
16 See also Ayres-Bennett (2016). Note that Tieken-Boon van Ostade (2011) offers a similar revisionist view of the work of Robert Lowth, who has equally often been termed an icon of prescriptivism.

17 Vaugelas's original spelling is retained, but the use of $u / v$ and $i / j$ is modernised for ease of reading.
} 
(you should use now one, now the other, so that it does not seem as if you are condemning the expression which you never use, which would be wrong, and so that we retain everything which contributes to the richness of our language, which includes being able to say the same thing in two different ways rather than simply in one.)

\section{Il n'y a rien de tel, il n'y a rien tel}

Tous deux sont bons, et il semble qu'en parlant on dit plustost il n'y a rien tel, que l'autre, mais qu'en escrivant, on dit plustost il n'y a rien de tel. Pour moy je voudrois tousjours escrire ainsi (Vaugelas 1647: 323).

(Both are acceptable, and it seems that in speaking you use il n'y a rien tel rather than the other, but in writing you use rather il n'y a rien de tel. Personally I would always write like that.)

As for explicit statements of intention, he states at the very outset of his work in his Preface that he views himself as a simple witness ('simple tesmoin') of usage:

Et tant s'en faut que j'entreprenne de me constituer Juge des differens de la langue, que je ne pretens passer que pour un simple tesmoin, qui depose ce qu'il a veu et oüi [...] C'est pourquoy ce petit Ouvrage a pris le nom de Remarques, et ne s'est pas chargé du frontispice fastueux de Decisions, ou de Loix, ou de quelque autre semblable; Car encore que ce soient en effet des Loix d'un Souverain, qui est l'Usage, si est-ce qu'outre l'aversion que j'ay à ces titres ambitieux, j'ay deu esloigner de moy tout soupçon de vouloir establir ce que je ne fais que rapporter (Vaugelas 1647: Preface I).

(Far from wishing to set myself up as a arbiter in linguistic disputes, I claim only to be a simple witness, who records what he has seen and heard [...] That is why this small work has been entitled Remarks, and has not been given a magnificent frontispiece with Decisions, or Laws, or some such. For although these are in effect the laws of a sovereign, namely Usage, nevertheless, in addition to the horror I have of such ambitious titles, I was obliged to distance myself from any suspicion of wanting to establish what I am only reporting.)

Furthermore, in two important methodological observations (1647: 503-509), he outlines the empirical procedure to be adopted if usage is doubtful or uncertain. In the first, he recommends that women and those unversed in Greek and Latin grammar should be consulted so that the informant gives a more authentic and natural judgment about actual usage. In the second, he advises that any such request for native speaker judgment should be formulated such that the informant does not realise what the point of language being researched is, so that $\mathrm{s} / \mathrm{he}$ avoids reasoning or thinking consciously about what s/he says. It should also be noted that the importance of following usage, and not reason, runs as a leitmotiv throughout the work.

However, Vaugelas's reputation as a prescriptivist comes from a number of other statements in the Preface, and notably in the definition of good usage, which moves from a descriptive norm ('usage') to an elitist norm ('good usage'), 
not defined in terms of the majority but rather the 'healthiest' part of speakers at the king's court and of the best writers:

Il y a sans doute deux sortes d'Usages, un bon \& un mauvais. Le mauvais se forme du plus grand nombre de personnes, qui presque en toutes choses n'est pas le meilleur, \& le bon au contraire est composé non pas de la pluralité, mais de l'élite des voix, \& c'est veritablement celuy que l'on nomme le Maistre des langues, celuy qu'il faut suivre pour bien parler, \& pour bien escrire en toutes sortes de stiles, si vous en exceptez le satyrique, le comique, en sa propre \& ancienne signification, \& le burlesque [...]. Voicy donc comme on definit le bon Usage. C'est la façon de parler de la plus saine partie de la Cour, conformément à la façon d'escrire de la plus saine partie des Autheurs du temps (Vaugelas 1647: Preface II).

(There are certainly two sorts of usage, good and bad. Bad usage comprises that of the majority of people, which in almost everything is not the best, and good usage on the contrary is comprised not of the plurality of voices, but of the elite, and that is certainly the one which is the Master of languages, which must be followed if you want to speak well and to write well in all sorts of styles, with the exception of satire, comedy, in its proper and ancient sense, and burlesque [...]. So this is how good usage is defined: it's the way the 'healthiest' part of the Court speaks as it conforms with the way the 'healthiest' authors of our time write.)

In terms of explicit statements of intention in the Preface and elsewhere in the text, then, we find a balance of descriptive and prescriptive concerns. Vaugelas's stated intended aim is to describe a particular variety of French, but one which he considers superior to others. Under this measure, we might consider him to be mildly prescriptive (2). If we place more emphasis on the elitist nature of the language he is describing, then we might consider him to be moderately prescriptive (3).

\section{Weighting of non-prescriptive (descriptive) elements in choice of metalanguage}

Analysis of the use of metalanguage in the actual observations demonstrates that classification of the metalanguage into prescriptive vs descriptive is far from straightforward. Some observations are clearly prescriptive in expression, as in the case of the remark entitled Subvenir, where Vaugelas acknowledges that his recommendation goes against the usage of most people and uses the classic prescriptive formulation il faut dire... et non pas...:

Subvenir

Il faut dire, subvenir à la necessité de quelqu'un, et non pas survenir, comme dit la plus part du monde; Car survenir veut dire toute autre chose, comme chacun sçait (Vaugelas 1647: 38). 
(One must say, subvenir à la necessité de quelqu'un, and not survenir, as most people speak. For survenir means something completely different, as everybody knows.)

On the other hand, some remarks are clearly descriptive in expression:

Periode

Ce mot est masculin quand il signifie le plus haut point, ou la fin de quelque chose, comme Monté au periode de la gloire; jusqu'au dernier periode de sa vie, Mais il est feminin quand il veut dire une partie de l'oraison qui a son sens tout complet Une belle periode, des periodes nombreuses (Vaugelas 1647: 3-4).

(This word is masculine when it means the highest point, or the end of something as in Having reached the acme of glory; until the very end [periodemasculine] of his life, but it is feminine when it refers to a part of speech which expresses a complete idea A fine sentence, harmonious sentences [periodefeminine].)

Other observations, however, are much less clear-cut and may show a mixture of prescriptive and descriptive expressions:

\section{Quelque}

Ce mot est quelquefois adverbe, et par consequent indeclinable. Il signifie alors environ. Il ne faut donc point y ajouster d's, quand il est joint avec des pluriels, comme il faut dire, Ils estoient quelque cinq cens hommes, et non pas quelques cinq cens: car là il n'est point pronom, mais adverbe (Vaugelas 1647: 4).

(This word is sometimes an adverb, and thus indeclinable. It means about. One must not add an $s$, when it is joined with plurals, so one should say, Ils estoient quelque cinq cens hommes, and not quelques cinq cens: for in this case it is not a pronoun, but an adverb.)

\section{Chypre}

Il faut dire l'Isle de Chypre, la poudre de Chypre, et non pas l'Isle de Cypre, la poudre de Cypre. L'Usage le veut ainsi, nonobstant son origine. Je pensois que M. de Malherbe eust esté le premier qui l'eust escrit de cette sorte, mais j'ay trouvé que M. de Montagne dans ses Essais, ne le dit jamais autrement (Vaugelas 1647: 6).

(One should say l'Isle de Chypre, la poudre de Chypre, and not l'Isle de Cypre, la poudre de Cypre. That is what usage requires, regardless of the word's origin. I thought that Malherbe was the first to write it in this way, but I've found that Montaigne in his Essays never expresses it in any other way.)

We analysed the first 50 observations in Vaugelas's Remarques, categorizing them into those which are clearly prescriptive in expression, those which are clearly descriptive, and those where there is a balance of elements or interpretation is 
more difficult. Using this small sample, $42 \%$ were clearly prescriptive, $30 \%$ clearly descriptive, and $38 \%$ fell into the mixed/indeterminate category. In terms of expression, then, we might characterise Vaugelas as moderately prescriptive (3), with a considerable amount of space being given to description/non-prescriptive material.

\section{Degree of reflection of current usage/variability/change}

In this section, I will consider together the next two interrelated areas, the extent to which the text describes current usage, variation and change.

There are certainly cases where the prescriptive language seems to reflect a prescriptive intent and the observation does not reflect current usage. The following is one such example:

Le pronom relatif $\mathrm{LE}$, devant deux verbes, qui le regissent

Par exemple envoyez moy ce livre pour le revoir \& augmenter. C'est ainsi que plusieurs personnes escrivent, je dis mesme des Autheurs renommez; Mais ce n'est point escrire purement, il faut dire pour le revoir \& l'augmenter, $\&$ repeter le pronom le, necessairement; [...] Cette Reigle ne souffre point d'exception (Vaugelas 1647: 33).

(The relative pronoun 'Le' before two verbs which govern it

For example, envoyez moy ce livre pour le revoir \& augmenter. Many people write like this, indeed even good authors. But that is not the pure way to write, it is obligatory to say pour le revoir \& l'augmenter, and essential to repeat the pronoun le [...] This is a rule without exception.)

Fournier (1998: 77) notes, however, that this ellipsis is frequent in seventeenth-century usage, especially with co-ordinated infinitives, possibly to convey the idea of a unified process. She cites a number of examples, including:

Il les traite et gouverne à sa fantaisie (Molière 1669)

Ils n'habitent d'anciens palais qu'après les avoir renouvelés et embellis (La Bruyère 1689).

In addition, we have examples of Vaugelas himself using this construction in his early translation of the Lenten sermons of the Spanish priest Fonseca, published in 1615:

mais Marcelle \& les autres qui sont avec elle le descouvrent \& manifestent haut \& clair (Vaugelas 1615: 461).

My previous research suggests, however, that such cases are relatively rare. Indeed, prescriptive language can mask an accurate presentation of what is 'normal' or of the 'descriptive norm', at least in written language. Amongst the cases I have illustrated elsewhere (Ayres-Bennett 2016), we may take as an example the observation on the form for the third person singular and plural of the passé simple of the verb prendre 'to take'. The observation clearly employs prescriptive language: 


\section{Print, prindrent, prinrent.}

Tous trois ne valent rien, ils ont esté bons autrefois, \& M. de Malherbe en use tousjours [...]. Mais aujourd'huy l'on dit seulement, prit, et prirent, qui sont bien plus doux (Vaugelas 1647: 98).

(All three are worthless, they used to be acceptable, and Malherbe always uses them [...] But today only prit and prirent are used, which sound much nicer.)

If we compare this comment with usage as represented in the database Frantext (www.frantext.fr), ${ }^{18}$ we find that Vaugelas's judgments are confirmed by usage in the texts. By 1647 the forms print, prindrent and prinrent are no longer attested, and only prit and prirent are used.

Similarly, in discussing the variation between commencer à and commencer de, Vaugelas tolerates only the former:

Ce verbe dans la pureté de nostre langue demande tousjours la preposition $\grave{a}$, apres soy, \& pour bien parler François il faut dire par exemple il commence à se mieux porter, \& non pas il commence de se mieux porter, \& cela est tellement vray, que mesme au preterit defini, à la troisiesme personne singuliere commença, il faut dire à apres, \& non pas de, comme disent les Gascons, \& plusieurs autres Provinciaux, \& mesme quelques Parisiens, soit par contagion, ou pour adoucir la langue ostant la cacophonie des deux $\grave{a}$, ne se souvenant pas de cette maxime sans exception, qu'il n'y a jamais de mauvais son qui blesse l'oreille, lors qu'un long usage l'a estably, \& que l'oreille y est accoustumée [...]. Il ne faut donc jamais dire il commença de, mais tousjours il commença $\grave{a}$, mesme quand le verbe qui suit commenceroit encore par un $\grave{a}$, tellement qu'il faut dire par exemple il commença à avoüer, \& non pas il commença d'avoüer (Vaugelas 1647: 424-426).

(If you are using our language purely, then this verb always requires the preposition $\grave{a}$ after it, and to speak French well you must say, for example, il commence à se mieux porter, and not il commence de se mieux porter, and this is so true that, even in the third person singular preterite commença, you must follow it with $\grave{a}$ and not $d e$, as the Gascons and various other provincials say, and even some Parisians, either by contamination or to sweeten the language by removing the cacophony of two à, forgetting this maxim without exception that there is no unpleasant sound which hurts the ears when a long usage has established it and your ear is accustomed to it [...]. So you must never say il commença de, but always il commença à [...].)

When we examine usage in Frantext, we observe that commencer de appears to have been 'fashionable' in the decade 1610-1619. By the 1630s, its usage seems to have declined in relation to that of commencer à, and by the 1640 s, the decade in which

\footnotetext{
18 Consulted for the different case studies between October 2010 and June 2013. Whilst there are a number of problems associated with the use of Frantext in terms of its representativeness and the choice of editions included, etc., it nevertheless provides a substantial body of evidence about contemporary written usage.
} 


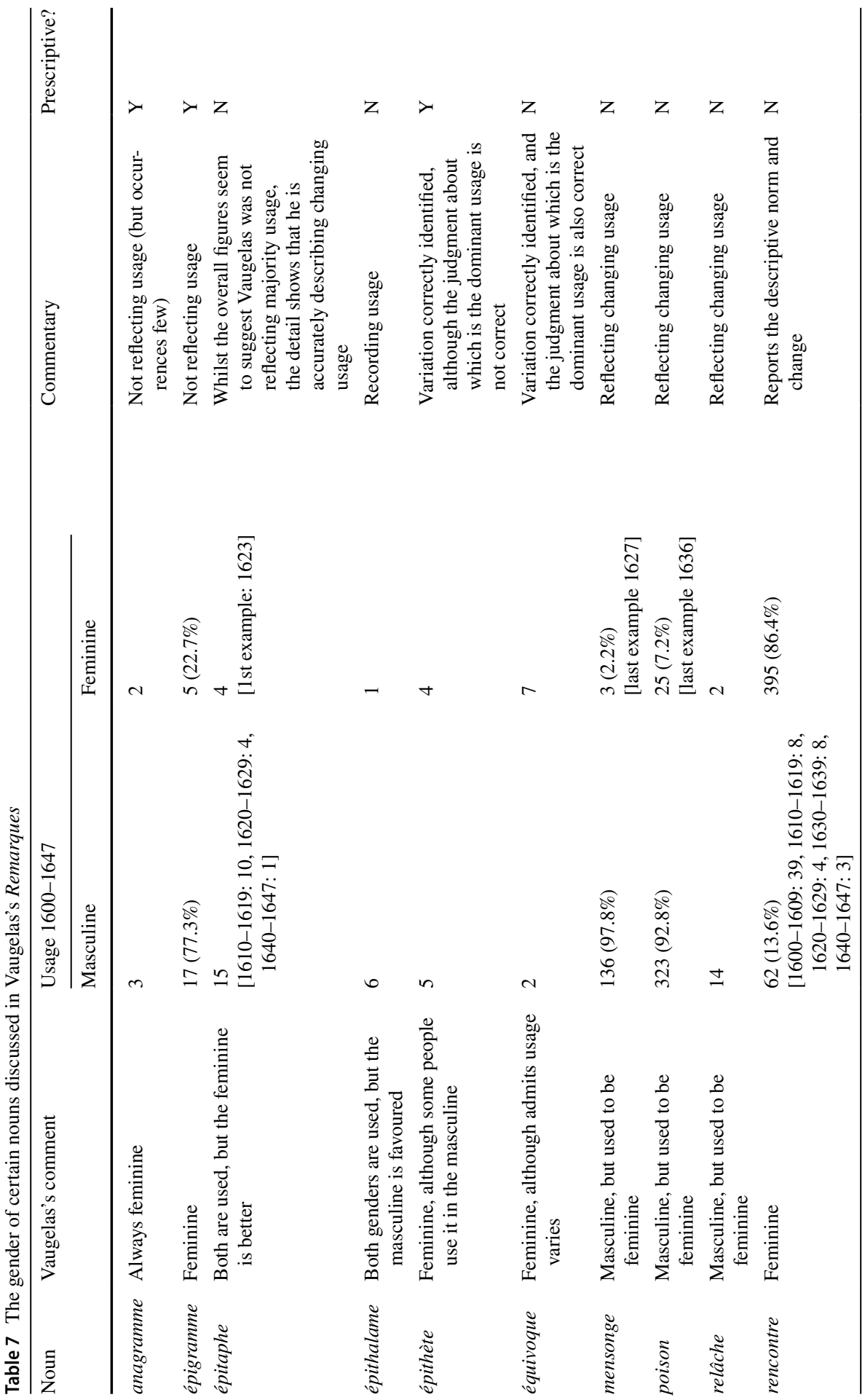




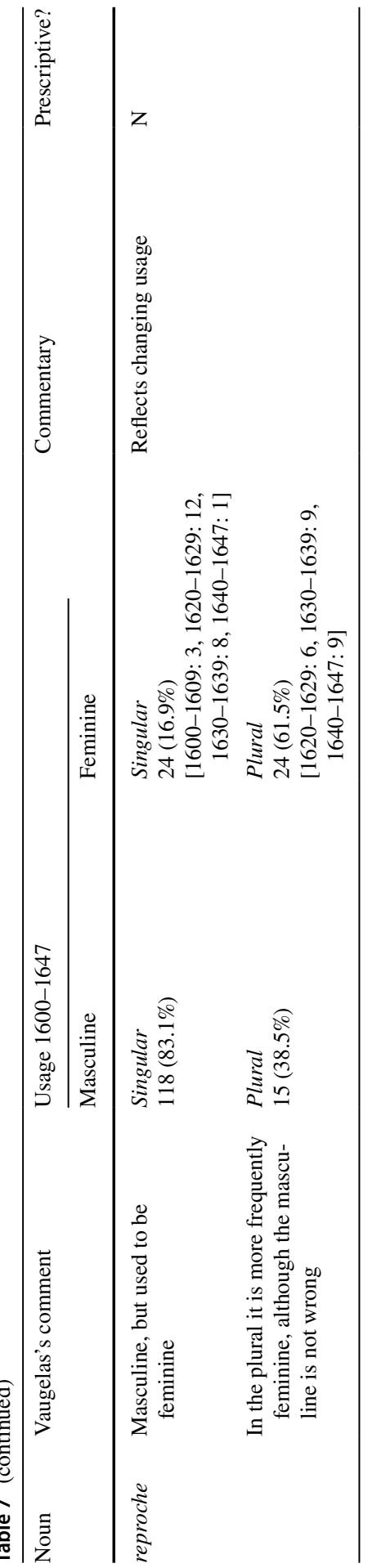


Vaugelas was writing, commencer $a$ is 11 times more common than commencer de. Looking at these data, we could argue that Vaugelas had rightly picked up the sharp downward trend in the use of commencer de and was thus justified in stating, at the time of writing, the relative importance of commencer $\grave{a}$. In other words, it seems that he correctly identified the apparent diachronic trend.

Another interesting area is the discussion of the grammatical gender of certain nouns, a number of which begin with a vowel (for further details, see Ayres-Bennett and Seijido 2011a: 124-131). ${ }^{19}$ In Table 7, I present data comparing Vaugelas's pronouncements with contemporary usage as represented in Frantext. Percentages (to one decimal place) are given where there are at least 20 occurrences for the period $1600-1647 .{ }^{20}$ Of the eleven cases discussed, Vaugelas is prescriptive in only three, and it is striking how accurately he seems to have been able to discern the pattern of changing usage, which I have demonstrated only through analysis of a very large database of texts.

In short, as far as this area is concerned, Vaugelas seems to reflect usage and its variation and change well. We might consider he displays only mild prescriptivism (1) in this area.

\section{Pattern of prescriptive development/effect}

In this section, I consider the extent to which Vaugelas was prescriptive in effect, or the extent to which his work influenced or changed usage. This category is perhaps the most difficult to evaluate and measure, since we cannot be sure that usage would not have continued to evolve in a certain way without the influence of metalinguistic texts, particularly if we believe that these reflect and record usage. It seems, then, that what we can measure is the potential impact a text or author might have had. We can also demonstrate where influence is not possible.

The first thing to note is that Vaugelas's reputation as being very prescriptive depends at least in part on how his work is filtered or represented by later grammarians and commentators. In other words, later commentators or compilers may make him appear more prescriptive. Four years after the publication of Vaugelas's observations, Jean Macé produced a compilation of these observations together with the comments of François de La Mothe Le Vayer, Scipion Dupleix and a third anonymous critic. The following example is typical of the kind of simplification ${ }^{21}$ :

Vitupere, vituperer

Ce mot n'est gueres bon, quoy que M. Coeffeteau s'en soit servy une fois ou deux dans son histoire Romaine, et que M. de Malherbe ayt dit,

\footnotetext{
19 I have excluded consideration of horoscope since the word is not attested in Frantext in the period 1600-1647. The assignment of nominal gender in French, as a largely arbitrary feature, is liable to becoming a social marker, and thus a question for prescriptivists.

20 The figures represent the number of occurrences of the noun in the singular except in the case of reproche, for which Vaugelas makes a distinction of gender for the singular and the plural noun. One of the reasons why the gender of these nouns was in doubt was the infrequency of their usage.

21 For more details, see Ayres-Bennett and Seijido (2011b).
} 
Et si de vos discords l'infame vitupere.

Je n'en voudrois user qu'en raillerie, \& dans le stile bas. Vituperer, ne vaut rien du tout (Vaugelas 1647: 412-413).

(Vitupere is hardly acceptable, although Mr Coeffeteau used it once or twice in his Roman history and Mr Malherbe said Et si de vos discords l'infame vitupere. I would only use it in jest, and in low style. Vituperer is worthless.)

Just four years later, in his compilation of observations, Jean Macé simplifies this observation radically, making it appear much more prescriptive:

On condamne vitupere, \& vituperer (Macé 1651: 245).

(Vitupere and vituperer are condemned.)

The assessment of the impact of Vaugelas Remarques on subsequent usage requires additional research, but I offer an example here. In Table 8, I reprise the information about usage in the period 1600-1647 and compare it with usage in the second half of the century, after the publication of the Remarques.

Discounting the case of anagramme (for which there are no data in the second period), and separating out the cases of reproche in the singular and the plural, these words can be divided into the six cases where, broadly speaking, there seems to be little or no evidence of Vaugelas having had any impact on subsequent usage, and the other five where Vaugelas's observation may have impacted on usage. It is worth reiterating here that potential impact does not mean that we have proof of actual impact, only that it exists as a possibility. We can further subdivide the first category, into two sub-types: in the case of épithalame and reproches (plural), Vaugelas's recommended usage is not the favoured one in the second half of the century, so there is clearly no impact on usage. In the case of épithète, équivoque, relâche and rencontre, similar patterns of usage remain, again suggesting little impact from the observation. Conversely, the clearest instance of possible impact comes from épigramme, where we see a clear shift towards the form prescribed by Vaugelas in the second half of the century. The modern gender of mensonge, poison and, to a lesser extent, of reproche in the singular is already well established before Vaugelas published his observations, and the most that can be said is that these may have reinforced the demise of the earlier usage. As for épitaphe, the trend towards increased use of the feminine also continues in the second half of the century, suggesting that Vaugelas correctly identified the direction of change.

In short, the evidence to suggest that Vaugelas's observations on gender were prescriptive in effect is relatively slight, and seems to remain at the level of mild prescription (1).

\section{Summary of findings}

Putting together the findings of this preliminary analysis, we arrive at the picture set out in Table 9. 


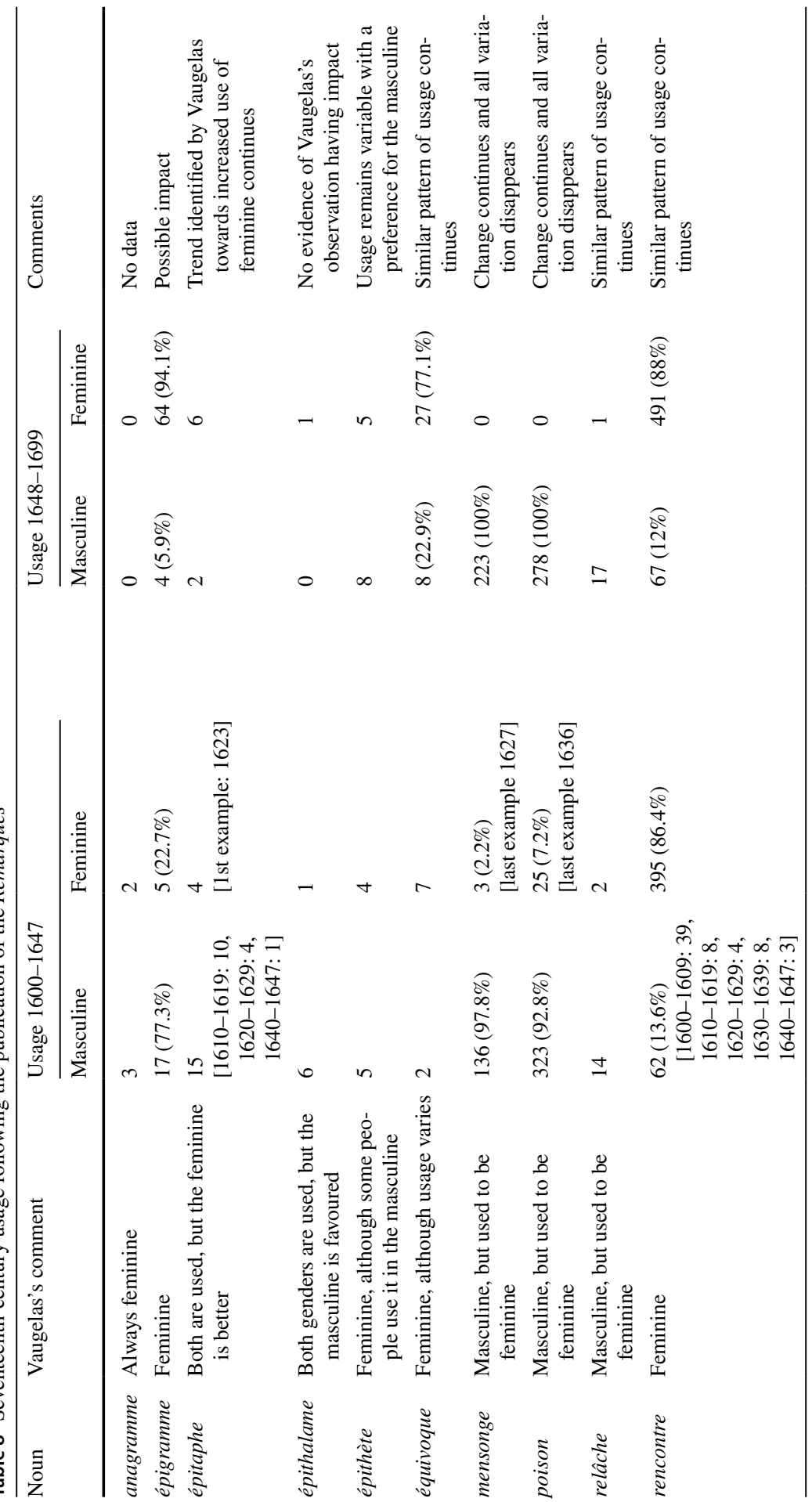




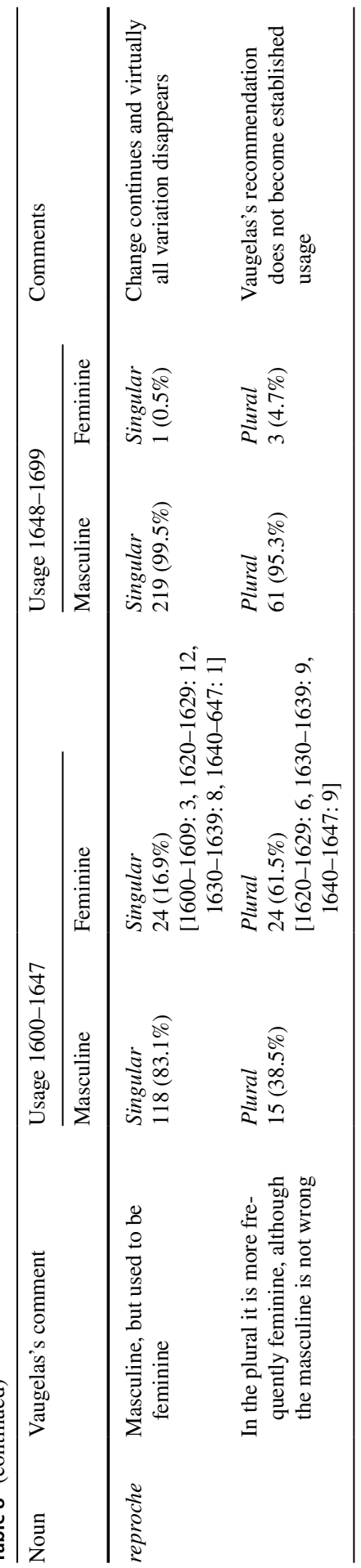


Table 9 Summary of the assessment of Vaugelas's prescriptivism

\begin{tabular}{|c|c|c|c|c|c|c|}
\hline \multirow{3}{*}{$\begin{array}{l}\text { Intensity criterion } \\
\text { (a) Weighting of non-prescriptive factors (intention) }\end{array}$} & \multicolumn{6}{|c|}{ Intensity level } \\
\hline & \multicolumn{2}{|c|}{ Mild } & \multicolumn{2}{|c|}{ Moderate } & \multirow{2}{*}{$\begin{array}{l}\text { Extreme } \\
5\end{array}$} & \multirow{2}{*}{$\frac{\text { Score }}{2 / 3}$} \\
\hline & 1 & 2 & 3 & 4 & & \\
\hline $\begin{array}{l}\text { (b) Weighting of non-prescriptive factors (expression/ } \\
\text { metalanguage) }\end{array}$ & 1 & 2 & 3 & 4 & 5 & 3 \\
\hline $\begin{array}{l}\text { (c) Degree of reflection of current usage/variability } \\
\text { (d) Degree of reflection of changing usage }\end{array}$ & 1 & 2 & 3 & 4 & 5 & 1 \\
\hline (e) Pattern of prescriptive development/effect & 1 & 2 & 3 & 4 & 5 & 1 \\
\hline Average & & & & & & 1.88 \\
\hline
\end{tabular}

Bearing in mind the need to be cautious about these scores, ${ }^{22}$ the table nevertheless confirms that Vaugelas is in practice much less prescriptive than has been traditionally thought, a reputation which at least in part relies on consideration of his use of metalanguage, which, as we have seen, is the most prescriptive element of his work. Application of this model to other grammarians would give us further insight into how prescriptive he is relative to others.

\section{Conclusion}

In this article, Haugen's category of codification was revisited and it was shown to require refinement. In particular, I explored the relationship between codification and prescription, which are not distinguished in Haugen's model, and considered the role of purism in linguistic standardisation, which is similarly conflated with prescriptivism in certain accounts. It was argued that the definition and interpretation of these concepts needs to be nuanced, and that it is important to distinguish between the author's/work's intention, use of metalanguage, and effect when analysing the role of both prescriptivism and purism in the development of a standard language.

Having made these distinctions, I further contended that description and prescription should not be viewed as a simple dichotomy, but rather as a continuum or cline, and outlined a model for evaluating an author's/a work's degree of prescriptivism, in parallel to George Thomas's proposals for assessing purism. In applying this framework to the work of Vaugelas, a so-called icon of prescriptivism, it became clear that he is much less prescriptive than has sometimes been claimed. It would be useful to extend this analysis to other metalinguistic texts and their authors to see whether similar results emerge.

\footnotetext{
${ }^{22}$ I have here used a figure of 2.5 for intention (criterion a). Note that if separate scores are given for (c) and (d), then the average becomes 1.7. This highlights the need to see these figures as only broadly indicative of the degree of prescriptivism.
} 
Acknowledgements This research, part of the Multilingualism: Empowering Individuals, Transforming Societies research project, was funded by the Arts and Humanities Research Council (AHRC) (Grant No. AH/N004671/1) under its Open World Research Initiative.

Open Access This article is distributed under the terms of the Creative Commons Attribution 4.0 International License (http://creativecommons.org/licenses/by/4.0/), which permits unrestricted use, distribution, and reproduction in any medium, provided you give appropriate credit to the original author(s) and the source, provide a link to the Creative Commons license, and indicate if changes were made.

\section{References}

Armstrong, N., \& Mackenzie, I. E. (2013). Standardization, ideology and linguistics. Basingstoke: Palgrave Macmillan.

Auroux, S. (1992). Introduction. Le Processus de grammatisation et ses enjeux. In S. Auroux (Ed.), Histoire des idées linguistiques (Vol. 2, pp. 11-64). Liège: Mardaga.

Ayres-Bennett, W. (2016). Codification and prescription in linguistic standardisation: Myths and models. In J. M. Nadal \& F. Feliu (Eds.), Constructing languages: Norms, myths and emotions (pp. 99-129). Philadelphia: John Benjamins.

Ayres-Bennett, W. (forthcoming). Refining models of language standardization. In W. Ayres-Bennett \& J. Bellamy (Eds.), The Cambridge handbook of language standardization. Cambridge: Cambridge University Press.

Ayres-Bennett, W., \& Seijido, M. (2011a). Remarques et observations sur la langue française: Histoire et évolution d'un genre. Paris: Éditions Classiques Garnier.

Ayres-Bennett, W., \& Seijido, M. (2011b). Les Compilations raisonnées des Remarques et Observations sur la langue française. French Studies, 65(3), 347-356.

Brincat, J. (2003). Purism and neologism in contemporary Maltese. In J. Brincat, W. Boeder, \& T. Stolz (Eds.), Purism in minor languages, endangered languages, regional languages, mixed languages: Papers from the conference on 'Purism in the age of globalisation', Bremen, September 2001 (pp. 155-170). Bochum: Brockmeyer.

Brincat, J., Boeder, W., \& Stolz, T. (Eds.). (2003). Purism in minor languages, endangered languages, regional languages, mixed languages: Papers from the conference on 'Purism in the age of globalisation', Bremen, September 2001. Bochum: Brockmeyer.

Brousseau, A.-M. (2011). Identités linguistiques, langues identitaires: Synthèse. In Arborescences: Revue d'études françaises, 1. http://id.erudit.org/iderudit/1001938ar. Accessed 8 May 2018.

Cameron, D. (1995). Verbal hygiene. London: Routledge (new edition 2012).

Cerquiglini, B. (2008). Merci professeur! Chroniques savoureuses sur la langue française. Paris: Bayard.

Coski, C. (2011). From barbarism to universality: Language and identity in early modern France. Columbia: University of South Carolina Press.

Costa Carreras, J. (2007). Réflexions sur la diffusion de la norme linguistique catalane. In A. Viaut (Ed.), Variable territoriale et promotion des langues minoritaires (pp. 287-300). Pessac: Maison des Sciences de l'Homme d'Aquitaine.

Curzan, A. (2014). Fixing English: Presciptivism and language history. Cambridge: Cambridge University Press.

Deumert, A., \& Vandenbussche, W. (Eds.). (2003). Germanic standardisations: Past to present. Amsterdam/Philadelphia: John Benjamins.

Ferguson, C. A. (1968). Language development. Reprinted in C. A. Ferguson (Thom Huebner Ed, 1991), Sociolinguistic perspectives: Papers on language in society, 1959-1994 (pp. 40-47). New York: Oxford University Press.

Fournier, N. (1998). Grammaire du français classique. Paris: Belin.

Gal, S. (2006). Migration, minorities and multilingualism: Language ideologies in Europe. In C. MarMolinero \& P. Stevenson (Eds.), Language ideologies, policies and practices. Language and the future of Europe (pp. 13-27). Basingstoke: Palgrave Macmillan. 
Haugen, E. (1972 [1966]). Dialect, language, nation. In J. B. Pride \& J. Holmes (Eds.), Sociolinguistics (pp. 97-111). Harmondsworth: Penguin (originally published in American Anthropologist, 68, 922-935).

Haugen, E. (1987). Blessings of Babel. Bilingualism and language planning problems and pleasures. Berlin: Mouton de Gruyter.

Hualde, J. I., \& Zuazo, K. (2007). The standardization process of the Basque language. Language Problems and Language Planning, 31(2), 143-168.

Joseph, J. E. (1987). Eloquence and power: The rise of language standards and standard languages. London: Frances Pinter.

Langer, N., \& Davies, W. V. (Eds.). (2005). Linguistic purism in the Germanic languages. New York: Walter de Gruyter.

Lodge, R. A. (1993). French: From dialect to standard. London: Routledge.

Macé, J. (1651). Methode universelle pour apprandre facilemant les langues, pour parler puremant et escrire nettemant en françois, recueillie par le sieur Du Tertre. Paris: Jean Jost.

Milroy, J. (2001). Language ideologies and the consequences of standardization. Journal of Sociolinguistics, 5(4), 530-555.

Milroy, J., \& Milroy, L. (1991). Authority in language: Investigating language prescription and standardisation (2nd ed.). London/New York: Routledge.

Nevalainen, T., \& Tieken-Boon van Ostade, I. (2006). Standardisation. In R. Hogg \& D. Denison (Eds.), A history of the English language (pp. 271-311). Cambridge: Cambridge University Press.

Paveau, M.-A., \& Rosier, L. (2008). La Langue française: Passions et polémiques. Paris: Vuibert.

Penny, R. (2000). Variation and change in Spanish. Cambridge: Cambridge University Press.

Stillwell, K., \& Hetrovicz, L. (2013). The standardizations of Catalan: Latin to present day. Studies in the Linguistic Sciences: Illinois Working Papers, 38, 68-86.

Thomas, G. (1991). Linguistic purism. London/New York: Longman.

Tieken-Boon van Ostade, I. (2011). The Bishop's grammar: Robert Lowth and the rise of prescriptivism in English. Oxford: Oxford University Press.

Trask, R. L. (1999). Key concepts in language and linguistics. London: Routledge.

Vaugelas, C. F. (1615). Les Sermons de Fonseque sur tous les Evangiles du Caresme: Avec une Paraphrase perpetuelle sur toutes les parties des Evangiles [...]. Paris: R. Thierry \& E. Foucault.

Vaugelas, C. F. (1647). Remarques sur la langue françoise utiles à ceux qui veulent bien parler et bien escrire. Paris: Veuve Jean Camusat \& Pierre Le Petit.

Walsh, O. (2016). Linguistic purism: Language attitudes in France and Quebec. Amsterdam: John Benjamins.

Publisher's Note Springer Nature remains neutral with regard to jurisdictional claims in published maps and institutional affiliations.

Wendy Ayres-Bennett is Professor of French Philology and Linguistics, University of Cambridge. She specialises in the history of French and the history of linguistic thought, on which she has published widely. Her research interests include standardisation and codification, linguistic ideology and policy, variation and change. She is Principal Investigator on the multi-disciplinary, multi-institution research project, Multilingualism: Empowering Individuals, Transforming Societies, funded by the AHRC under its Open World Research Initiative (2016-2020). The project is working closely with policymakers and practitioners to promote the value of languages for key issues of our time and the benefits of language learning for individuals and societies. 